\title{
A fuzzy model for assessing the impact of factors on free urban plots
}

\author{
M. I. Tsiutsiura, A. V. Yerukaiev \\ https://doi.org/10.31174/SEND-NT2018-157VI17-18 \\ Kyiv National University of Construction and Architecture \\ *Corresponding author. E-mail: alusion@ukr.net
}

Paper received 16.01.18; Accepted for publication 22.01.18.

\begin{abstract}
This article considers a fuzzy model for assessing the factors that affect free urban land allocated for the construction of apartment buildings. This model combines the methods of strategic planning and artificial intelligence, namely: SWOT analysis, Zade's fuzzy sets and Mamdani's fuzzy logic inference, as well as the main components of the genetic algorithm. The results of its application are presented in the form of graphs, which reveal the advantages of using the model under consideration on the basis of studies conducted in one of the largest cities of Eastern Europe - the city of Kiev.
\end{abstract}

Keywords: SWOT analysis, fuzzy sets, genetic algorithm.

Introduction. In the condition of modern intensive building of large cities, the developer faces the problem of choosing among the available land plots of exactly the one that, when investing in it for the construction of an apartment building, will bring the greatest profit from the completion of the completed facility. But each site under consideration is influenced by a variety of influencing factors: social, administrative, economic, political, environmental, etc. Of these factors, less than $10 \%$ can be measured by standard methods, and all the others are of a qualitative nature. In view of the reasons considered, a choice was made in favor of fuzzy sets, which are the basis of the proposed model for assessing the impact factors on land plots.

Overview of publications. Among the available sources that sanctify this issue, special attention should be paid to the following: in [1] a model is considered, the basis of which was used by the authors to construct the current fuzzy model; in [2] a detailed description of fuzzy sets is presented; in [3] the scheme of the genetic algorithm, as well as its main components, is fully disclosed; and finally in [4] a detailed description of the process of fuzzy inference, which was proposed by Mamdani.

Goal. Increase the efficiency of the use of unfinished plots for the needs of housing construction due to the model of fuzzy assessment of the influencing factors. To improve the quality characteristics of the future apartment building and, accordingly, to improve the tenants' residence in this house in terms of minimizing the waste of time and money in their daily affairs.

Materials and methods. As mentioned above, the model under consideration is the result of combining the most popular methods of strategic analysis and artificial intelligence. A general view of this model is shown in Figure 1.

It is soft calculations as a section of artificial intelligence through their simplicity and approach to the mapping of human thinking and were chosen to construct a fuzzy model for assessing land plots.

Since there are many groups of influencing factors and new ones inevitably appear in the process of research, it is necessary to group them in such a way that it is possible to work with them conveniently. For this purpose, a SWOT analysis has been chosen, thanks to which, irrespective of the number of factors studied, the work will be carried out with only four categories: strengths (S), weaknesses $(\mathrm{W})$, opportunities $(\mathrm{O})$ and threats $(\mathrm{T})$.
And just to describe the impact of the relevant categories of SWOT, i.e. result (R), as well as to give more flexibility and expand the scope of the results obtained, the fuzzy Zadeh logic was involved.

The membership functions of fuzzy sets, which describe SWOT categories, are not of a standard form, since the opinions of experts on the evaluation of urban land plots were used for their construction in order to make the task more practical. These constructions were carried out using the following formula [4]:

$$
\mu_{l_{j}}\left(u_{i}\right)=\frac{1}{K} \sum_{k=1, K} b_{j, i}^{k}, i=\overline{1, n},(1)
$$

In formula (1), the following notation is used:

- $K$ - number of experts;

- $b_{j, i}^{k}$ - opinion of the $k$ expert about the presence of an element $u_{i}$ of fuzzy set properties $\tilde{l}_{j}, k=\overline{1, K}$, $i=\overline{1, n}, j=\overline{1, m}$;

$$
\text { - } \tilde{l}_{j}=\left(\frac{\mu_{l_{j}}\left(u_{1}\right)}{u_{1}}, \frac{\mu_{l_{j}}\left(u_{2}\right)}{u_{2}}, \cdots, \frac{\mu_{l_{j}}\left(u_{n}\right)}{u_{n}}\right) \text { - fuzzy set, }
$$

which describes the linguistic term $l_{j}, j=\overline{1, m}$, on the universal set $U$.

Accordingly, in the process of their construction, all the requirements for the membership functions were taken into account, so that they had the correct uncertainty [2]. Therefore, the resulting terms describe this model according to the existing reality in the construction market.

Each of the 4 SWOT categories is described in the form of fuzzy sets according to the template shown in Figure 2, which describes the structure of the accessories functions. Thus, the following terms exist, in an amount equal to five [2], which have the following common names:

- minimal (for S: negative, for $\mathrm{W}$ : bad, for O: negative, for T: bad and for R: insignificant);

- medium-minimum (for S: satisfactory, for W: satisfactory, for O: satisfactory, for T: satisfactory, and for R: small);

- average (for S: more than satisfactory, for W: more than satisfactory, for $\mathrm{O}$ : more than satisfactory, for $\mathrm{T}$ : more than satisfactory and for R: average);

- medium-high (for S: moderately positive, for W: almost good, for O: moderately positive, for T: almost good and for R: almost large);

- maximum (for S: positive, for $\mathrm{W}$ : good, for O: positive, for T: good, and for R: large). 


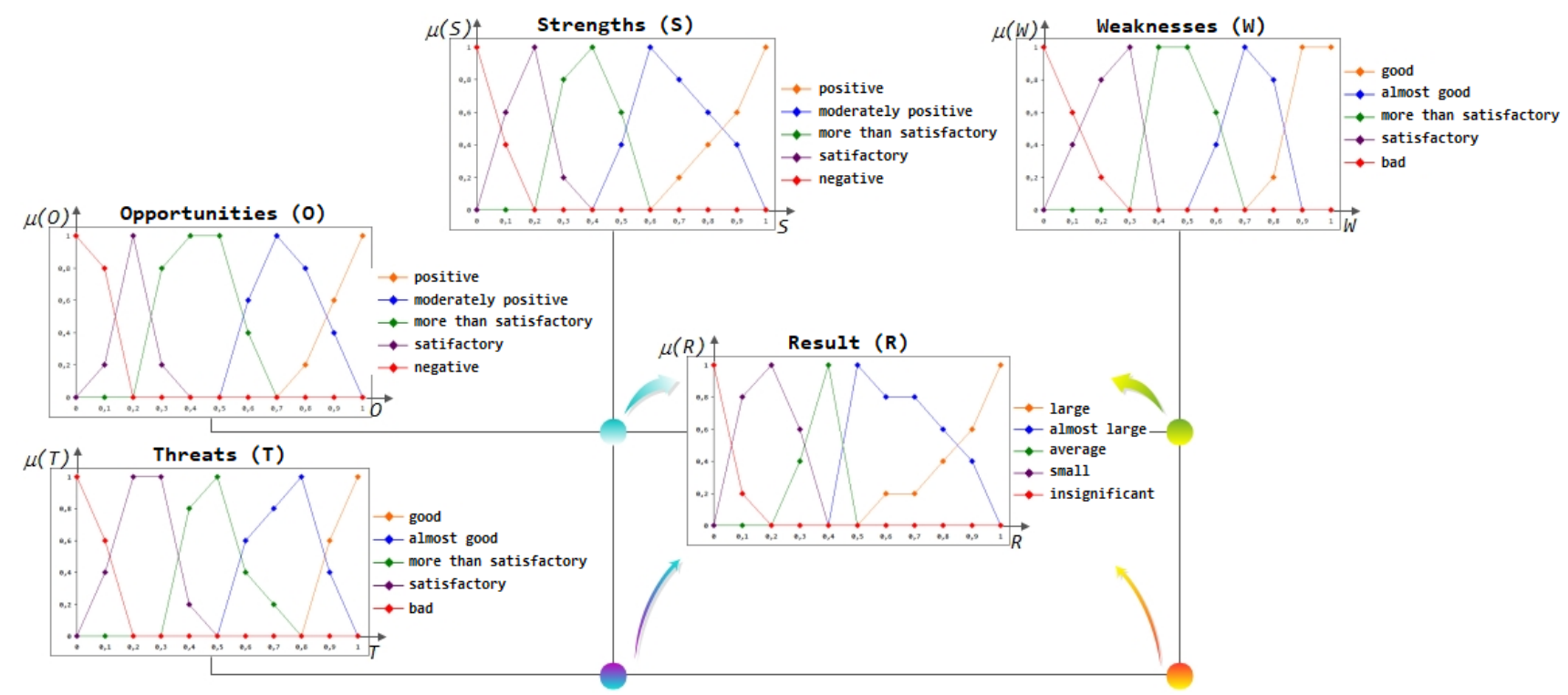

Fig. 1. Fuzzy model for assessing the impact of factors on urban land plots

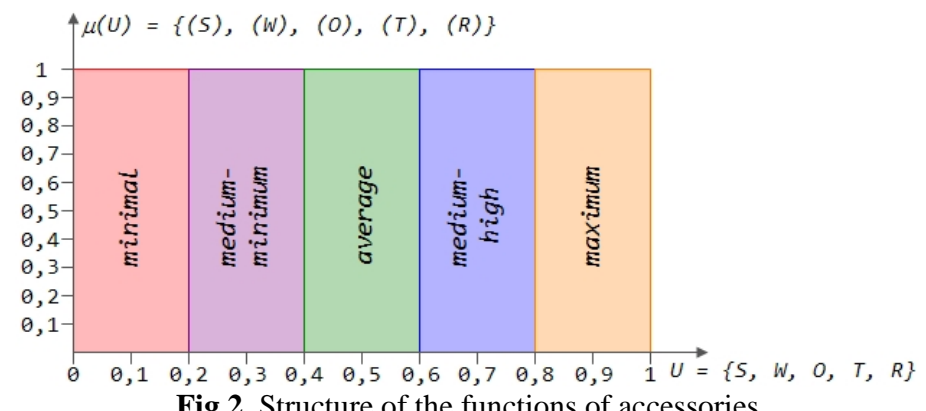

Fig.2. Structure of the functions of accessories

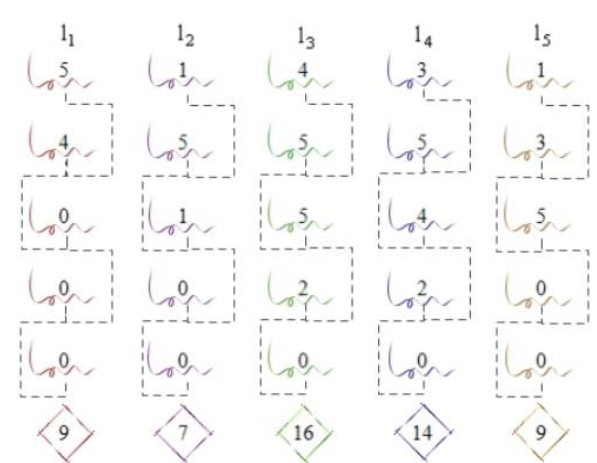

Fig. 3. The initial population and its fitness functions

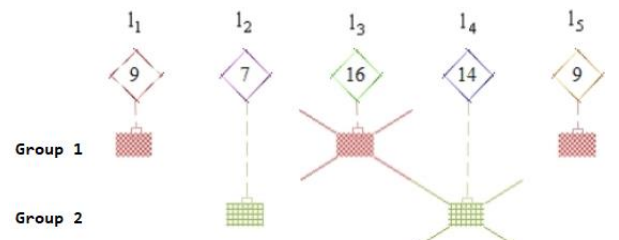

Fig. 4. Tournament selection with indication of the winners

In order to make the dynamic model in question, or in other words, the ability to change over time, a technology known as the genetic algorithm was used.

In other words, due to the opinion of experts on the evaluation of land plots, the functions of accessories of fuzzy sets were obtained. But, since the assessment can change, a mechanism is needed that will automate this process. The solution was the application of the evolutionary approach.

Thanks to him, such concepts and possibilities as a gene, an individual, a population, a function of adaptation, etc. were used, so that the kind of accessories functions could be changed. Figure 3 shows an example of the initial population of a fuzzy set.

From the figure above, it can be seen that genes were used to display values $\mu$ (in fact, this is the number of expert voices that evaluated the specific value of the universal set $\mathrm{U}$. The value $\mu$ is obtained by dividing the given number by the number of experts' votes involved this number $\mu$ ), and individuals - to display the functions of accessories. The population thus obtained is nothing but a fuzzy set.

Using the methods of genetic algorithm: selection (Figure 4), crossing and mutation - we get the final population.

The figure shows the result of the tournament selection with the indication of the winners. As can be seen from this graphical scheme, the winners are those that have the greatest fitness function.

As was said above in the course of the evolutionary algorithm, situations may arise where the membership function ceases to meet the requirements imposed on it by the theory of fuzzy sets. It's about its visual appearance, when a concave function can turn out. To correct this problem, a mutation is used. An example of its application is shown in Figure 5. 


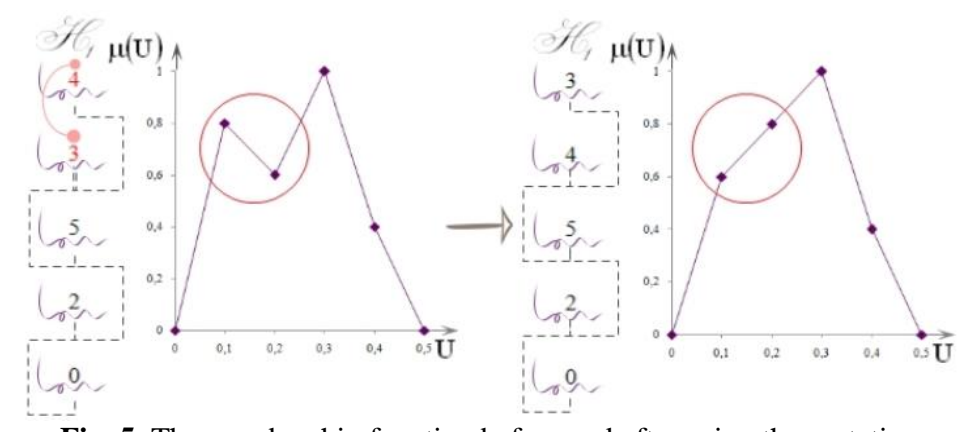

Fig. 5. The membership function before and after using the mutation

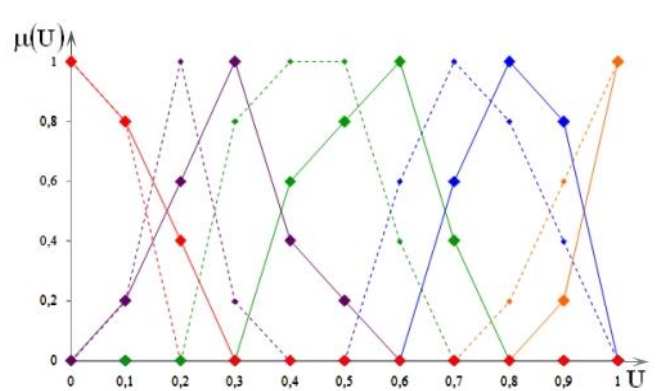

Fig. 6. Kind of functions of accessories of the final population

The result obtained after applying the genetic algorithm will be the same fuzzy set, but with different values $\mu$ for its accessory functions.

To illustrate this process, Figure 6 shows two "temporary snapshots" of fuzzy set membership functions that describe the category "Strength": obtained before apply- ing the genetic algorithm on the basis of expert opinions (in the form of dotted lines) and after its application (in the form of solid lines).

The fuzziness obtained in assessing the land plot can be reduced to a specific number using a technique known as fuzzy logic inference. Its methods (aggregation, accumulation, dephasing) make it possible to translate a fuzzy assessment into a clear, unambiguous one. Among the existing technologies, one was chosen that uses the simplest methods that were proposed by the scientist Mamdani [4].

Applying the Mamdani method to the obtained accessory functions, 2 results were obtained on the basis of which the test plot was constructed (Figure 7), where it is said that the genetic algorithm is more cautious in working with the influencing factors, which gives ample opportunities for further evaluation of factors and their use.

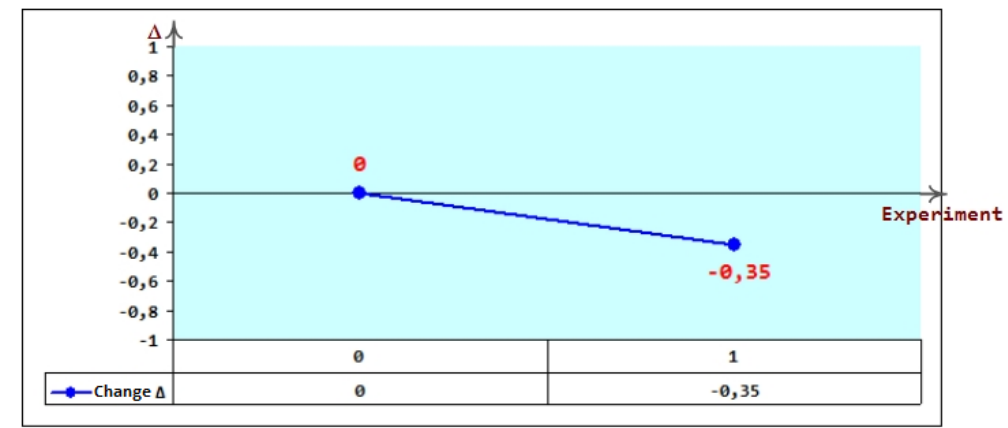

Fig. 7. The graph of the influence of the factors of the pair of categories $\mathrm{S}$ and $\mathrm{O}$ on the test land plot

Conclusions. Based on the model examined, 10 specific plots for an apartment building in the city of Kiev were analyzed. The resulting graph (Figure 8) directly indicates that the best site for development is at number 9 (the values are taken to the maximum).

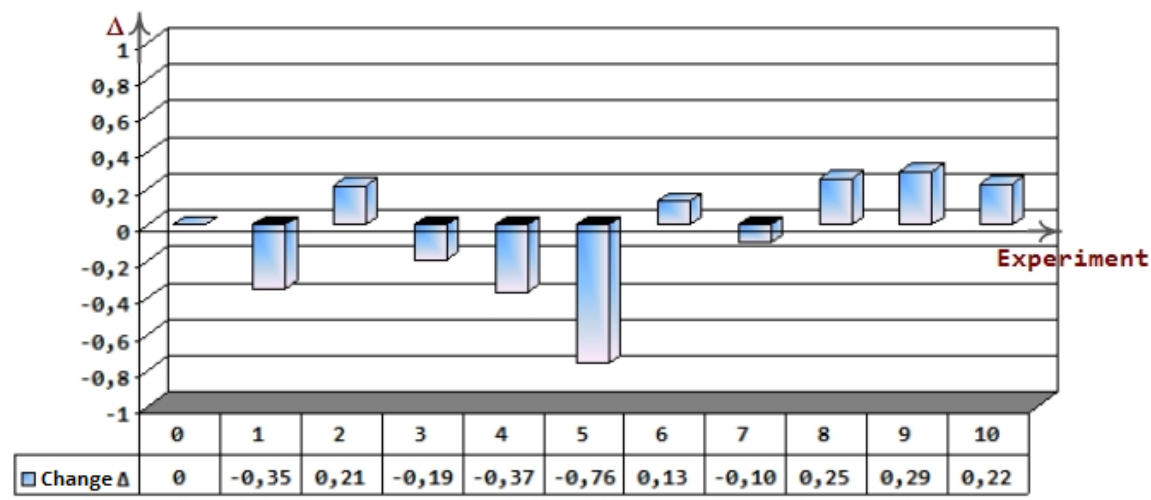

Fig. 8. Graph of the impact of the factors of all four pairs of SWOT categories 


\section{ЛИТЕРАТУРА}

1. Мицель А.А. Применение нечетких лингвистических моделей при разработке стратегии развития муниципального образования // Известия Томского политехнического университета, 2005. 4 (308), С. 177-182.

2. Леоненков А.В. Нечеткое моделирование в среде MATLAB и fuzzyTECH - СПб.: БХВ - Петербург, 2014. $736 \mathrm{c}$.

3. Рутковская Д. Нейронные сети, генетические алгоритмы и нечеткие системы - М.: Горячая линия - Телеком, 2013. $384 \mathrm{c}$.

4. Штовба С.Д. Проектирование нечетких систем средствами MATLAB - M.: Горячая линия - Телеком, 2007. - 288 c.

\section{REFERENCES}

1. Micel' A.A. Application of fuzzy linguistic models in the development of the strategy for the development of the municipality // Izvestija Tomskogo politehnicheskogo universiteta, 2005. 4 (308), C. 177-182.

2. Leonenkov A.V. Fuzzy modeling in the MATLAB and fuzzyTECH environment - SPb.: BHV - Peterburg, 2014. $736 \mathrm{c}$.

\section{Нечеткая модель оценки влияющих факторов на свободные городские участки}

\section{Н. И. Цюцюра, А. В. Ерукаев}

Аннотация. В данной статье рассматривается нечеткая модель оценки факторов, которые влияют на свободные городские земельные участки, выделенные для строительства многоквартирных домов. Данная модель объединяет в себе методы стратегического планирования и искусственного интеллекта, а именно: SWOT-анализ, нечеткие множества Заде и нечеткий логический вывод Мамдани, а также основные компоненты генетического алгоритма. Результаты ее применения представлены в виде графиков, в которых раскрыты преимущества использования рассматриваемой модели на основании проведенных исследований в одном из самых больших городов Восточной Европы - городе Киеве.

Ключевые слова: SWOT-анализ, нечеткие множества, генетический алгоритм. 